\title{
Effect of different micro climate on the physiological parameters and yield of capsicum
}

\begin{abstract}
The study carried out to determine the effect of different micro climate on the physiological parameter and yield of capsicum (Capsicum annuиm L.) at Plasticulture farm, CTAE, Udaipur, Rajasthan. There are four small structures $(1,2,3$ and 4$)$ of $64 \mathrm{~m}^{2}(16 \mathrm{~m} \times 4 \mathrm{~m})$ area each with varying cladding material i.e., $75 \%$ shade net, 40 mesh insect net, 200 micron LDPE UV stabilized sheet air vent on side and top provided with $75 \%$ shade net, and 200 micron LDPE UV stabilized sheet and air vent on side and top provided with insect net, respectively. It was observed that maximum plant height $(174.7 \mathrm{~cm})$, leaves per plant (64) and first harvesting (57.3 DAT) was found in structure-1. Early flower initiation (29 DAT) was found in Structure-2. Maximum number of flower per plant (23.7), cumulative number of flower per plant (18.20), highest individual fruit weight (94.4 g), highest fruit yield $(1720 \mathrm{~g} / \mathrm{plant}$ ) were found in structure-4. The water use efficiency was found 14.62 $\mathrm{kg} / \mathrm{m}^{3}, 13.52 \mathrm{~kg} / \mathrm{m}^{3}, 15.17 \mathrm{~kg} / \mathrm{m}^{3}$ and $18.91 \mathrm{~kg} / \mathrm{m}^{3}$ under structure-1, structure-2, structure-3 and structure-4 respectively. Based on the results, structure-4 was found best in respect of yield, physiological yield, physiological parameters, maximum net income (Rs. 13813/- per structure i.e. Rs. $215.83 / \mathrm{m}^{2}$ area) and B:C ratio (1.87).
\end{abstract}

Keywords: capsicum, physiological parameters, crop yield, shade net house, insect net house, structures etc
Volume 3 Issue 2 - 2019

\author{
Chitra Shukla,' SK Acharya, ${ }^{2}$ SR Bhakar, ${ }^{3}$ PK \\ Jamrey ${ }^{4}$ \\ IIndian Institute of Technology, Kharagpur, India \\ 2Professor, College of Technology \& Engineering, India \\ ${ }^{3}$ College of Horticulture, SDAU, India \\ ${ }^{4}$ Agriculture Department, Ramakrishna Mission Ashrama \\ Narayanpur, India
}

Correspondence: SK Acharya, Asstt Professor College of Horticulture SDAU Jagudan Distt Mehsana (Gujarat) 384 460, Tel +91-7359039097, India, Email sanjay.acharyahort@gmail.com

Received: October 31, 2018 | Published: April 05, 2019

\section{Introduction}

The increasing global demand for food and other agricultural products calls for urgent measures to increase unit crop production in terms of land and water. Concerning this problem protected cultivation is scientific intervention through which production can be multiplied many times per unit land and per unit water. Capsicum botanically known as Capsicum annuиm placed in Solanceae family and classified as fruit vegetable crop. It is 6-10 months crop under protected conditions. One can take the production advisable to do the greenhouse farming. With the development of facility protected cultivation, acreage of capsicum is increasing under greenhouse to pursue the maximum economic profits. However, its cultivation is confined to warm and semi-arid countries where water is often a limiting factor for production. ${ }^{1}$ The crop grown under open conditions will not fulfill the export standards, so the search for new avenues has led to development of Hi-Tech precision horticultural systems. Greenhouse, the latest word in Indian agriculture is one such means, where the plants are grown under controlled or partially controlled environment resulting in higher yields than that possible under open conditions $^{2}$ in capsicum. Protected structure is created locally by using different types of material. These structures are designed as per climatic requirements of the area for different sets of environmental conditions. Growing of capsicums under cover has been reported to give good quality produce with higher productivity. Recently, few entrepreneurs have started its cultivation under protected conditions like greenhouse; shade house etc. to get higher productivity and quality adopting the hybrids supplied by the private companies. Now a day apart from green color, other varieties like red, yellow, light green are also available. However, there is a need to assess the performance of capsicum hybrids under different structures to advise small and marginal farmers of the regions to get higher unit returns.

The main purpose of protected cultivation is to create a favorable environment for the sustained growth of crop so as to realize its maximum potential even in adverse climatic conditions. It has very high entrepreneurial value and profit maximization leading to local employment, social empowerment and respectability of the growers. The greenhouse covering materials play a very important role in defining the microclimate based on their transmissivity, ${ }^{3}$ also impacting different energy balance components such as sensible, latent heat flows and transpirations and photosynthetic processes. ${ }^{4,5}$ The choice of the greenhouses cover material is essential for optimizing crop production. The scientific information regarding interaction between environment and capsicum fruit yield and quality is still lacking. Therefore, this study aimed to evaluate and compare the effects of different types of cladding material on physiological parameter of capsicum crop.

\section{Materials and methods}

The experiment was carried out at Plasticulture farm CTAE Udaipur. Experiment has been laid out inside four small size structure of $16 \mathrm{~m} \mathrm{x} 4 \mathrm{~m}$ size each. The plant was transplanted at a spacing of $50 \mathrm{~cm} \mathrm{x} 30 \mathrm{~cm}$ and a structure consists 400 plant (100 plant per raised bed). Irrigation was given through gravity fed drip irrigation system of 4 laterals in each structure. The crop was taken during January 2013 to July 2013. The capsicum has been grown under four small sizes, naturally ventilated protected structures that are shade net house, insect net house, poly house with shade net vents, poly house with insect net vents, during February to July, 2013 at plasticulture farm CTAE Udaipur. Four types of raised arch shaped structures were used for study- stucture-1: Structure fully covered with shade net;stucture-2: Structure fully covered with insect proof net; stucture-3:Structure covered with $200 \mu$ LDPE polythene and natural ventilation through shade net (Top of the structure covered by polythene sheet, side opening and top vents covered by shade net with provision of $1.0 \mathrm{~m}$ wide apron from the ground); stucture-4: Structure covered with $200 \mu$ LDPE polythene and natural ventilation through shade net (Top of the structure covered by polythene sheet, 
side opening and top vents covered by insect net with provision of 1.0 $\mathrm{m}$ wide apron from the ground); The standard packages of practice were followed during entire crop period and standard management practices have been followed as per the guide line of plant protection measures. Various plant physiological and inside climatic parameters such as plant height $(\mathrm{cm})$, number of leaves per plant, time required for first harvest number of flowers per plant, number of fruits per plant, per cent fruit set, fruit weight $(\mathrm{g})$, fruit yield per plant $(\mathrm{kg})$, fruit yield (ton/ha), temperature $\left({ }^{\circ} \mathrm{C}\right)$, and relative humidity $(\%)$ were recoreded under each structure. Standard statistical methods were used to analyse the observed data.

\section{Results and discussion}

Plant height (Table 1) was noted maximum $(174.7 \mathrm{~cm})$ in structure-1, which was significantly superior over the other three growing structures. The least plant height $(147.6 \mathrm{~cm})$ was recorded under structure-2 at 150 DAT. During the successive stages of crop growth viz., 30, 60, 90 and 120 days after transplanting (DAT), the plant height of capsicum was found to be increasing and it was 174.7 $\mathrm{cm}$ at 150 DAT under structure-1, followed by structure-4 (162.0 $\mathrm{cm})$. This may be attributed to the enhanced plant metabolic activities like photosynthesis and respiration due to favorable micro-climatic conditions that prevailed in the structure- 1 as compared to structure- 4 . The results of higher growth rate under structures were also reported by Maurer ${ }^{6}$ in bell pepper and More et al. ${ }^{7}$ in cucumber.

Table I Effect of different types of growing structures on plant height of Capsicum cv. 'Indira'

\begin{tabular}{llllll}
\hline \multirow{2}{*}{$\begin{array}{l}\text { Growing } \\
\text { structure }\end{array}$} & \multicolumn{3}{l}{ Plant height $(\mathbf{c m})$} \\
\cline { 2 - 6 } & 30 DAT & 60 DAT & 90 DAT & I20 DAT & I50 DAT \\
\hline Structure I & 91.7 & 122.2 & 137.5 & 150.2 & 174.7 \\
Structure 2 & 68.9 & 101.2 & 110.4 & 132.6 & 147.6 \\
Structure 3 & 77.6 & 112 & 122.6 & 141.5 & 159.9 \\
Structure 4 & 78.6 & 113.2 & 124.7 & 142.5 & 162 \\
SEm+ & 1.758 & 2.198 & 3.079 & 3.734 & 3.079 \\
CD at 5\% & 5.625 & 7.031 & 9.85 & 11.948 & 9.85 \\
CV (\%) & 4.44 & 3.92 & 4.97 & 5.27 & 3.82
\end{tabular}

Number of leaves (Table 2) per plant was obtained maximum (64.1) in structure-1, which was significantly superior over the other three growing structures. The least No. of leaves per plant (46.6) was recorded under structure-2 at 150 DAT. This might be due to the taller

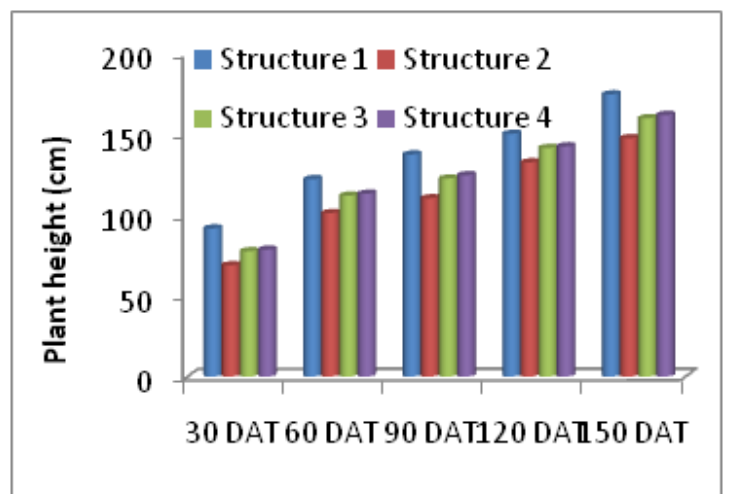

plants, increased number of branches and the congenial microclimate that prevailed inside the structure-1, favoring increased growth rate of plants. Similar results were obtained by Ochigbu et al. ${ }^{8}$ in cucumber.

Table 2 Effect of different types of growing structures on plant no. of leaves per plant of Capsicum cv. 'Indira'

\begin{tabular}{llllll}
\multirow{2}{*}{$\begin{array}{l}\text { Growing } \\
\text { structure }\end{array}$} & \multicolumn{5}{l}{ No. of leaves/plant } \\
\cline { 2 - 6 } & 30 DAT & 60 DAT & 90 DAT & I 20 DAT & I50 DAT \\
\hline Structure I & 13.8 & 24 & 39.6 & 47.9 & 64.1 \\
Structure 2 & 6.9 & 15.2 & 30.8 & 31.4 & 46.6 \\
Structure 3 & 9 & 19.3 & 34.9 & 39.1 & 55.3 \\
Structure 4 & 9.6 & 19.8 & 35.4 & 39.7 & 55.9 \\
SE m+ & 0.428 & 0.702 & 0.598 & 1.33 & 1.274 \\
CD $(P=0.05)$ & 1.37 & 2.248 & 1.914 & 4.257 & 4.078 \\
CV (\%) & 8.72 & 7.19 & 3.41 & 6.73 & 4.6 \\
\hline
\end{tabular}

Early flower initiation (29.0 DAT) was recorded under structure-2, which was significantly superior over the other structures (Table 3 ). The late flower initiation (34.3 DAT) was noticed in structure-1. The early first harvesting of plant i.e. 57.30 DAT was observed under structure-1 while, the late first harvesting of plant i.e. 66.7 DAT was noted under structure-3. This may be due to accumulation of maximum photosynthates favouring fast growth which triggered early initiation of flowers under Structure-2. Similar results were obtained by Rui et al. ${ }^{9}$ in capsicum. Effect of different growing structure on plant height and No. of leaves per plant has graphically represented in Figure 1.

Table 3 Effect of different types of growing structures on time taken for flower initiation and to first harvest of Capsicum cv. 'Indira'

\begin{tabular}{lll}
\hline Growing structure & $\begin{array}{l}\text { No. of days } \\
\text { to flowering }\end{array}$ & $\begin{array}{l}\text { No. of days to } \\
\text { first harvest }\end{array}$ \\
\hline Structure I & 34.3 & 66.7 \\
Structure 2 & 29 & 57.3 \\
Structure 3 & 31.7 & 63.3 \\
Structure 4 & 30.7 & 60.7 \\
SE m+ & 0.756 & 1.401 \\
CD $(P=0.05)$ & 2.42 & 4.482 \\
CV (\%) & 4.82 & 4.52 \\
\hline
\end{tabular}

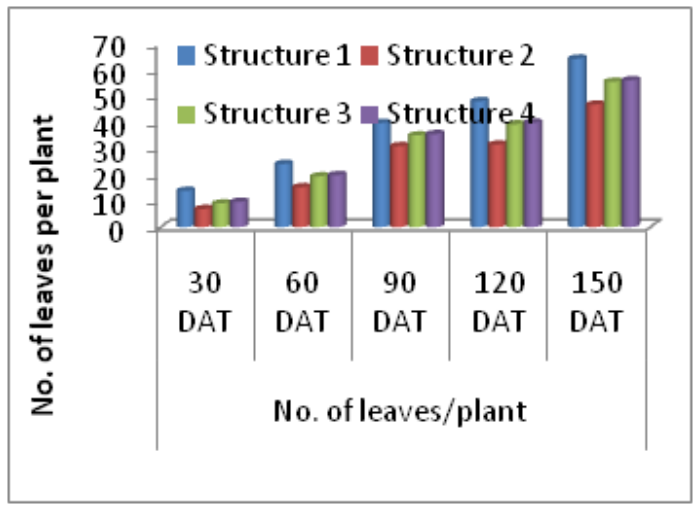

Figure I Effect of different growing structure on plant height and No. of leaves per plant. 
The maximum numbers of flower (Table 4) per plant i.e.23.7, was recorded under structure-4, while the minimum number of flower per plant i.e. 19, were noted under structure-1 at 150 DAT. At last harvesting (150 DAT), among the different structures, cumulative number of fruits per plant was observed maximum (18.2) under structure-4, which was significantly superior over the all other structures while, the least number of fruits per plant (14.9) was recorded under structure-1. Plants grown under structure-4 recorded more (25.0) numbers of flowers per plant followed by structure-2, (23.5) at 150 DAT. This could be attributed to the increased number of secondary branches per plant.

Table 4 Effect of different types of growing structures on number of flower and fruits per plant of Capsicum cv. 'Indira'

\begin{tabular}{llllll}
\hline \multirow{2}{*}{ Growing structure } & \multicolumn{2}{l}{ No. of flower/plant } & \multicolumn{2}{l}{ No. of fruits per plant } \\
& 60 DAT & 90 DAT & I 20 DAT & I50 DAT & \\
\hline Structure I & 11.5 & 13.6 & 16.9 & 19.4 & 14.9 \\
Structure 2 & 14.8 & 16.9 & 20.3 & 22.7 & 17.5 \\
Structure 3 & 13.9 & 16 & 19.4 & 21.8 & 16.8 \\
Structure 4 & 15.8 & 17.9 & 21.3 & 23.7 & 18.2 \\
SE m+ & 0.473 & 0.473 & 4.473 & 0.473 & 0.364 \\
CD (P=0.05) & 1.515 & 1.515 & 1.515 & 1.515 & 1.165 \\
CV $(\%)$ & 6.77 & 5.88 & 4.86 & 4.32 & 4.32 \\
\hline
\end{tabular}

Maximum fruit set (77.66 \%) was recorded under structure-1, which was significantly superior over the all other growing structures (Table 5). The minimum fruit set $(71.86 \%)$ was recorded under Structure-4. The highest individual fruit weight (94.4g) was recorded under structure-4, which was significantly superior over the all other growing structures while, the lowest yield $(82.3 \mathrm{~g})$ was recorded under structure-2. This was a consequence of production of more flowers per plant and less interference of adverse climatic conditions like rainfall and wind velocity during crop growth and development.

Table 5 Effect of different types of growing structures on percent fruit set of Capsicum cv. 'Indira'

\begin{tabular}{ll}
\hline Growing structure & Percent fruit set (\%)* \\
\hline Structure- I & $77.66(74.48)$ \\
Structure-2 & $76.86(74.20)$ \\
Structure-3 & $76.83(73.56)$ \\
Structure-4 & $71.86(72.77)$ \\
SE m+ & 0.39 \\
CD $(P=0.05)$ & 1.25 \\
$C V(\%)$ & 1.04 \\
\hline
\end{tabular}

*Data are arcsine transformed values, actual value is given under parenthesis
The number of fruits (Table 4) per plant was higher (18) at 150 DAT, under structure-4 followed by structure-2 (17.5). This might be due to the more number of flowers and maximum per cent fruit set under Structure-4. Similar observations were recorded by Backer ${ }^{10}$ for sweet pepper.

The higher fruit yield per plant $(1720 \mathrm{~g} / \mathrm{plant})$ was recorded under Structure-4, which was significantly superior over the all other growing structures while, the lowest yield (1285 g/plant) was recorded under structure-1 (Table 6). The marketable fruit yield of capsicum was higher $(1720 \mathrm{gm} / \mathrm{plant}$ and $68.8 \mathrm{ton} / \mathrm{ha})$ under structure-4 as compared to structure-1 (1285 g/plant and 51.4 ton/ha). This may be attributed to the favorable climatic conditions that prevailed under structure-4, leading to higher vegetative growth, contributing to more number of flowers, more number of fruits, higher per cent of fruit set, maximum fruit weight and fruit volume. Similar results were obtained by Nagendra Prasad ${ }^{11}$ in capsicum crop.

The maximum temperature observed under structure-3, i.e. 50.7 ${ }^{0} \mathrm{C}$, and the minimum temperature was recorded under structure-2, i.e. $9.4{ }^{\circ} \mathrm{C}$. The maximum relative humidity observed under structure- 1 , i.e. $89.9 \%$, and the minimum relative humidity was recorded under structure-3, i.e. $81.7 \%$. Variation in average inside temperature and relative humidity under different growing structure during February to July, 2013 has graphically represented in Figure 2.

Table 6 Effect of different types of growing structures on quantitative parameters of Capsicum cv. 'Indira'

\begin{tabular}{|c|c|c|c|c|}
\hline Growing structure & fruit weight (g) & Fruit yield/plant $\quad(g)$ & Fruit yield/sqm area $(\mathrm{g})$ & Fruit yield (ton/ha) \\
\hline Structure I & 86.2 & 1285 & 5140 & 51.4 \\
\hline Structure 2 & 82.3 & 1440 & 5760 & 57.6 \\
\hline Structure 3 & 91.4 & 1535 & 6140 & 61.4 \\
\hline Structure 4 & 94.5 & 1720 & 6880 & 68.8 \\
\hline SE m+ & 2.45 & 51.06 & 225.15 & 2.25 \\
\hline$C D(P=0.05)$ & 7.82 & 163.36 & 720.31 & 7.2 \\
\hline CV (\%) & 5.52 & 6.83 & 7.53 & 7.53 \\
\hline
\end{tabular}



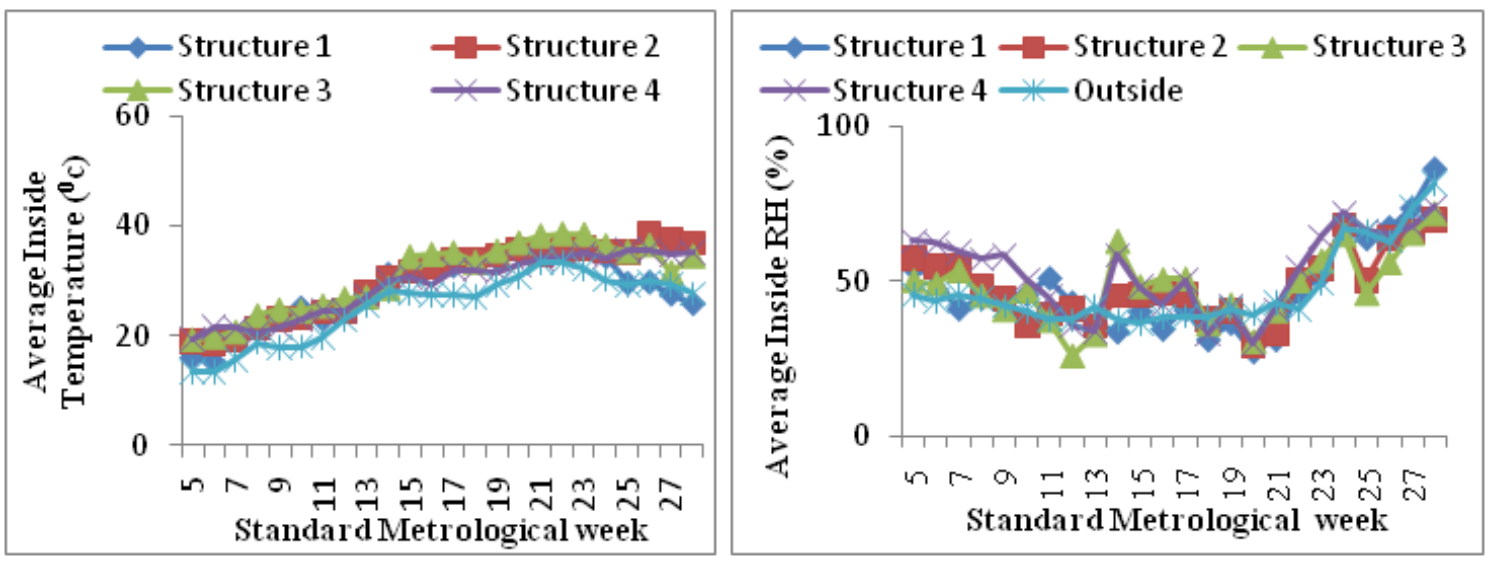

Figure 2 Variation in average inside temperature and relative humidity under different growing structure during February to July, 2013.

The maximum light intensity observed under structure-2, i.e. $228.5 \mathrm{watt} / \mathrm{m}^{2}$, and the minimum light intensity was recorded under structure-1, i.e. $136.0 \mathrm{watt} / \mathrm{m}^{2}$. Variation inside light intensity (K lux) and solar radiation $\left(\mathrm{Watt} / \mathrm{m}^{2}\right.$ ) under different growing structure during February to July, 2013 has graphically represented in Figure 3.
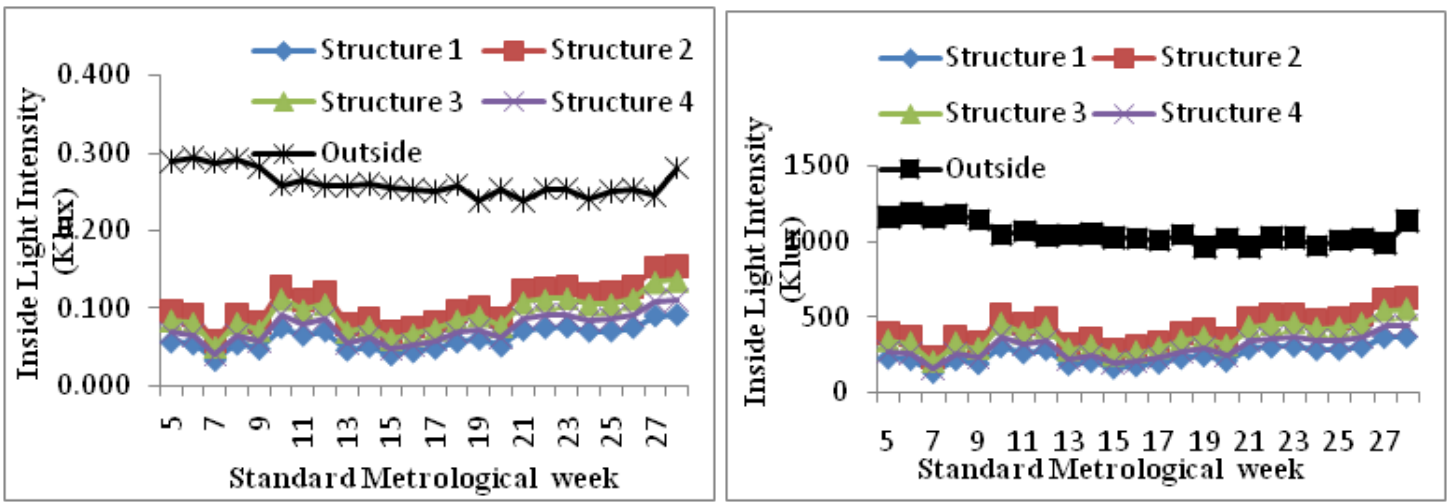

Figure 3 Variation inside light intensity (Klux) and solar radiation (Watt $\left./ \mathrm{m}^{2}\right)$ under different growing structure during February to July, $20 \mathrm{I} 3$.

Environment is the aggregate of all external conditions which influences the growth and development of crop, that which play dominant role in crop production. Each crop has its own set of environmental conditions under which it grows best. Generally, crops are not profitable unless they are adapted to the region in which they are produced. Raising a crop successfully means the crop must be productive and economical to grower under prevailing conditions.

Among the environmental factors, the temperature, relative humidity and light intensity are the factors which mainly influence the crop growth and development considerably. Solar radiation consists of different wave lengths of light, in which only the visible portion is useful for crop growth, while ultraviolet and infrared radiations are not beneficial for the crop growth, as they bring changes at molecular level that leads to cellular disorganization of the crops grown under open environment. However, excellent growth and higher yield is generally realized in the crops grown under shadenet house, because the covering structure has the property of absorbing UV and infrared radiations.

Temperature is the major regulator of the development process. It influences the flower and fruit development. Temperature was higher in the month of April under Structure-1. The effect of temperature on net photosynthesis is of vital concern in crop production. The higher temperatures have more adverse influence on net photosynthesis than lower temperature leading to decreased production of photosynthates above a certain temperature. ${ }^{12}$ The temperature can be controlled and regulated under protected structure, therefore healthy and better growth of plants can be expected under protected structures.

Atmospheric moisture also plays a significant role in crop growth and development. The maximum relative humidity was recorded in the month of July under polyhouse. The relative humidity increases the availability of net energy for crop growth and prolongs the survival of crops under moisture stress conditions, which leads to optimum utilization of nutrients. It also maintains turgidity of cells. The light intensity was maximum in the month of April under Structure-1. The water use efficiency was found $14.6 \mathrm{~kg} / \mathrm{m}^{3}, 13.5 \mathrm{~kg} / \mathrm{m}^{3}, 15.2 \mathrm{~kg} / \mathrm{m}^{3}$ and $18.9 \mathrm{~kg} / \mathrm{m}^{3}$ under structure-1, structure-2, structure-3 and structure-4 respectively. It has been found maximum under structure- 4 and minimum under structure-2.

The highest Net income of Rs. 13813/- per structure (means Rs. 215.83 per sqm area) and $\mathrm{B}: \mathrm{C}$ ratio of 1.87 , under structure- $4 .{ }^{13}$

\section{Conclusion}

It is concluded that the maximum plant height, leaves per plant and first harvesting was found in structure-1. Early flower initiation was found in structure-2. Maximum number of flower per plant, cumulative number of flower per plant, highest individual fruit weight, highest fruit yield and WUE were found in structure-4. After comparing 
given four structure type, structure- 4 showed best response of yield and physiological parameters. Net income of Rs. 13813/- per structure (i.e. Rs. 215.83 per sqm area) and $\mathrm{B}: \mathrm{C}$ ratio of 1.87 was estimated for structure-4. Therefore, structure- 4 may be recommended to the capsicum growers of the regions.

\section{Acknowledgments}

Authors are thankful to College of Technology \& Engineering, Maharana Pratap University of Agriculture and Technology, Udaipur, 313001, Rajasthan, India

\section{Conflicts of interest}

Authors declare that we have no conflict of interest.

\section{References}

1. Dorjia K, MH Behboudiana, JA Zegbe D, et al. Water relations, growth, yield and fruit quality of hot pepper under deficit irrigation and partial rootzone drying. Sci Hort. 2005;104:137-149.

2. Navale AV, SB Nandagude, AG Pawar,et al. Comparative study of capsicum skirting and top covering effect in low cost greenhouse. In: Proc. All India Sem. potential prospects for protective cultivation institute of engineers, Ahmednagar, 2003;12-13:97.

3. Finch DA, Bailey WG, McArthur LJB, et al. Photosynthetically active radiation regimes in a southern African savanna environment Agricultural and Forest Meteorology. 2004;122:229-238.

4. Stanghellini C, Jianfeng D, Kempkes FLK, et al. Effect of nearinfrared-radiation reflective screen materials on ventilation requirement, crop transpiration and water use efficiency of a greenhouse rose crop. Biosystems Engineering. 2011;110:261-271.
5. Ferrari DL, Leal PA. Use of thermoreflective screens on greenhouses for tomato production. Engenharia Agrícola, 2005;35(.2):180-191,

6. Maurer AR. Tunnel production of peppers, Research Review. 1981;15:86-93.

7. More TA, Chandra P, Majumdar G, et al. Some observations on growing cucumber under plastic greenhouse In: Proceedings of X1 international congress on the use of plastics in agriculture. 1990;49-55.

8. Ohigbu AA, Harris GP. Effect of film plastic cover on the growth and yield of bush tomato grown in a bed system. Journal of Horticultural Sciences. 1989;64(1):61-68.

9. Rui RL, YQ Nie, HY Tong. Protective effect of plastic film coverage on photosynthesis of capsicum in summer. Jiangsu Agriculture Science. $1989 ; 8: 30-31$

10. Backer JC. The effect of air humidity on flowering, fruit set and fruit growth of glass house sweet pepper (Capsicum annuиm L.). Scientia Horticulture. 1989;40:1-8.

11. Nagendra Prasad HN. Effect of plant density on growth and yield of capsicum grown under greenhouse and open conditions. M. Sc. (Agri.) Thesis submitted to University of Agricultural Sciences Bangalore; 2001.

12. Bhatt RM, NKS Rao. Response of bell pepper to photo- synthesis, growth flower and fruit setting to night temperature. Photosynthetica. 1993;28:127-132.

13. Aldrich RA, JW Bartok. Northeast regional agricultural engineering service, Cooperative extension, Greenhouse engineering. Ithaca, NY.1989. 